\title{
EFFECTIVE ACCESS TO DEFENCE COUNSEL IN THE JUDICIAL STAGE OF POLISH CRIMINAL PROCEEDINGS IN THE SCOPE OF DIRECTIVES 2013/48/EU AND 2016/1919/EU
}

\author{
Adrian Zbiciak*
}

\begin{abstract}
The article analyses certain regulations of the Polish Code of Criminal Procedure regarding the right of the accused to access a defence counsel, limited to the stage of proceedings before a court, in the context of the provisions of the two European Union's legal acts regarding this issue: Directive 2013/48/EU and Directive 2016/1919/EU. The provisions of the Polish CCP give the opportunity to maintain the standard of Directive 2013/48. However, the problem may occur when there is an ex officio defence counsel appointed and the court would decide to proceed in his/her absence. As for the standard arising from Directive 2016/1919, Polish provisions regarding the stage of judicial proceedings meet the European standard to a level even higher than the minimum. The only significant problem may arise from the obligation to submit an application for the appointment of an ex officio defence counsel within a specified period, but still due to specific solutions provided in Polish CCP, the standard of 2016 Directive is implemented.
\end{abstract}

Key words: access to a defence counsel; ex officio lawyer; court proceedings; EU directive; implementation in the Polish law

MA, Department of Criminal Procedure, Faculty of Law, Canon Law and Administration, The John Paul II Catholic University of Lublin, Al. Racławickie 14, 20-950 Lublin, Poland; e-mail: adrian.zbiciak@kul.pl; https://orcid.org/0000-0002-9501-8611. 


\section{INTRODUCTORY REMARKS}

The article analyses certain regulations of the Polish Code of Criminal Procedure ${ }^{1}$ regarding the right of the accused to access a defence counsel, limited to the stage of proceedings before a court, in the context of the provisions of the European Union's two legal acts regarding this issue: Directive 2013/48/EU of the European Parliament and of the Council of 22 October $2013^{2}$ (hereinafter: "Directive 2013/48" or "Directive of 2013") and Directive of the European Parliament and of the Council 2016/1919 of 26 October $2016^{3}$ (hereinafter: "Directive 2016/1919" or "Directive of 2016"). The first Directive sets a minimum standard for EU Member States regarding access to a lawyer in general, while the second concerns the guarantee of minimum standards for the Member States to provide ex officio lawyer.

The "stage of proceedings before a court" in the article is understood as the time from the public prosecutor's indictment (and other "complaints" initiating court proceedings) to the final decision, including the appeal hearing. The term "lawyer", used in the Directive and sometimes in the article, should be read as a "defence counsel" within the meaning of Article 82 of the CCP.

Analysis of the provisions of the Polish CCP as regards the access to a lawyer in the jurisdictional stage of criminal proceedings should be preceded by a key remark that depending on the understanding of the term used in the Directive, "the obligation to ensure the right to access a counsel defence", there may be different assessments of whether the provisions of the Polish CCP meet the minimum standard resulting from the Directive of 2013. It should be noted at the outset that neither Directive

\footnotetext{
1 Act of 6 June 1997, Official Journal 2020, item 30, hereinafter: "CCP" or "the Polish CCP”.

2 Official Journal EU L.2013.294.1. The full title: "Directive on the right of access to a lawyer in criminal proceedings and in European arrest warrant proceedings, and on the right to have a third party informed upon deprivation of liberty and to communicate with third persons and with consular authorities while deprived of liberty".

3 Official Journal EU L.2016.297.1. The full title: "Directive on legal aid for suspects and accused persons in criminal proceedings and for requested persons in European arrest warrant proceedings".
} 
2013/48 nor Directive 2016/1919 contain an unequivocal rule that would imply an absolute obligation to provide each accused with the assistance of a defence counsel paid by the State.

The statement of the Polish authorities, which indicates that there is no need to further adapt the Polish law to implement the Directive, indicates that the provisions of the Directive should be understood within the meaning that the Member States must guarantee the possibility of having the assistance of a defence counsel to the accused, unless the accused has one ${ }^{4}$.

This article only analyses the provisions regarding the stage of judicial proceedings, passing over the issues of the access to a lawyer in pre-trial proceedings, including the stage of court proceedings in the pre-trial stage (for instance when the court sitting is to decide on detention on remand, or hearing of witnesses by court, etc.).

\section{ACCESS TO A LAWYER WITHIN THE MEANING OF DIRECTIVE 2013/48}

The key to answer the question on whether the Polish provisions regarding the participation of a defence counsel (at the stage of court proceedings) meet the minimum standard set out in the Directive of 2013, is to define what should be understood as "the obligation to ensure the right of access to a lawyer". Article $3 \$ 1$ of the Directive states, that Member States shall ensure accused persons the right to access a lawyer in such time and in such a manner so as to allow the persons concerned to exercise their rights of defence practically and effectively. The most important for the discussed problem is, however, the content of Article $3 \$ 3$ of the Directive $2013 / 48$, where the scope of the term "right to a lawyer" has been specifically defined. This right therefore includes the obligation to ensure:

4 Reply of the Minister of Justice to the Ombudsman's pronouncement of 18 October 2018, available at: https://www.rpo.gov.pl/sites/default/files/Odpowied\%C5\%BA\%20 MS\%2018.10.2018_0.pdf. Pronouncement of Ombudsman of 4 July 2018 to the Minister of Justice: https://www.rpo.gov.pl/sites/default/files/Wyst\%C4\%85pienie\%20do\%20 Ministra\%20Sprawiedliwo\%C5\%9Bci\%20w\%20sprawie\%20prawa\%20osoby\%20zatrzymanej\%20do\%20pomocy\%20prawnej.pdf - [both date of access: 15.02.2020]. It is worth mentioning that the Polish Ombudsman's doubts relate to the pre-trial proceedings. 
1) the right to meet in private and to communicate with the representing lawyer, also before being questioned by the police or another law enforcement or judicial authority;

2) the right to the presence and effective participation of a lawyer during the questioning of the accused;

3) the right to the presence of a lawyer during the following evidence-gathering acts: identity parades (presentation for recognition), confrontation, reconstruction of the scene of a crime (trial experiment).

After even a cursory analysis of this provision, the conclusion can be drawn that the EU legislator does not require that in any case the accused be represented by a lawyer in a criminal court. The Directive of 2013, therefore, as regards the stage of judicial proceedings, sets a minimum standard to be provided by EU Member States in terms of access to a defence counsel, but it refers to the lawyer, whom the accused already has. In this case, national provisions are to guarantee that the accused's lawyer will be able to effectively perform his/her duties and thus the accused will have a real right of defence guaranteed.

The Directive of 2013 in this respect provides three groups of guarantees: the first concerns the possibility of meeting and communicating with a lawyer, the second is to guarantee the participation of the lawyer in the interrogation of the accused, and the third - the participation of the lawyer in three other specific evidence-gathering acts.

Therefore, first of all, it is necessary to analyse, in terms of the abovementioned three areas, the provisions of the Polish CCP, which apply in the event that the accused has a lawyer (both by choice and ex officio). Next, it is necessary to look separately at the question of appointing a state-paid defence counsel.

\section{ACCESS OF THE ACCUSED TO THE LAWYER WHOM HE/SHE ALREADY HAS}

In a situation where there are no grounds to appoint a defence counsel ex officio, the lawyer is appointed by the accused himself/herself, but if the accused is deprived of liberty, the defence counsel may also be appointed 
for him/her by relatives (Article $83 \$ 1$ of the CCP). If the accused is a minor or incapacitated, defence counsel may also be appointed by his/ her legal representative or the person under the care of whom the accused remains (Article 76 of the $\mathrm{CCP}$ ). The accused may have a maximum of three lawyers at the same time (Article 77 of the CCP).

At the stage of court proceedings, the first area of guarantee, i.e. the right to meet with a lawyer in private and to communicate with him/ her, does not in fact have any legal or actual limitations when the accused remains at liberty. It is worth pointing out that in the Polish CCP there are no rules on this issue, and the only restriction may be that the order shall be maintained in the courtroom during the trial. Communication of the accused with the defence counsel during the trial may take place even on an ongoing basis, e.g. during the interrogation of a witness - there is no prohibition here, provided that it does not interfere with the course of activities. There is also no obstacle for a defence counsel or for the accused to request a break in order to allow them to consult outside the courtroom. Insofar as such the request would not be overused (which the chairman of the panel would assess in each case in the realities of a particular situation), the institution of a break in the hearing (Article $401 \S 1$ of the CCP) could be used to execute the right of communication of the accused with his/her lawyer in private 5 .

The problem of a possible restriction of the accused's access to defence counsel could be revealed when the accused is deprived of liberty. However, it should be emphasized that at the stage of court proceedings, the Polish CCP does not allow any restrictions regarding the contact of the accused deprived of liberty with the defence counsel, in contrast to the pre-trial stage, where pursuant to Article $73 \$ 2$ and $\$ 4$ of the CCP the prosecutor may exceptionally stipulate that he/she will be present when

5 In Article $401 \$ 1 \mathrm{CCP}$ it is directly mentioned, that the break in the hearing can be decided in order to allow for the preparation of motions concerning evidence, which sometimes requires direct contact and discussion between the lawyer and the accused. The literature indicates that a break in the hearing may be ordered due to the state of health of the lawyer who appeared at the hearing but is not able to fully perform his duties - Ryszard Ponikowski, Jarosław Zagrodnik, "Commentary on the Article 401 CCP", In: Code of Criminal Procedure. Comment, ed. Jerzy Skorupka, Warszawa: C. H. Beck, 2018, 1028. 
the suspect contacts the lawyer, which can only take place during the first 14 days from the start-date of detention ${ }^{6}$.

The Polish legislator reasonably recognized that at the stage of court proceedings such a limitation in the accused's contacts with his/her lawyer could not be justified. In fact, the only restriction on the access to a lawyer may result from the very fact of the penitentiary isolation of the accused, but this is a matter of factual, not legal problem and is a natural consequence of imprisonment. The accused person, deprived of liberty, has the right to contact his/her lawyer, also during personal visits. CCP provisions do not contain any restrictions on the communication of the accused with the defence counsel so there are no obstacles at the stage of the court proceedings with the implementation of the Directive 2013/48 in the first guarantee ${ }^{7}$.

At the stage of court proceedings, the threat to the guarantees regarding the other two groups of situations explicitly mentioned in the Directive, i.e. the participation of the defence counsel in the interrogation of the accused and in the three specific evidence-gathering acts is also much less significant than in the pre-trial proceedings, which does not mean, however, that it is completely unreal.

It is worth starting this issue with the fact that an important guarantee of the accused's access to the lawyer at the stage of court proceedings are the provisions regarding the obligation to notify the lawyer about the date and place of each procedural act, including in principle also the dates of the hearing (Article $117 \$ 1 \mathrm{CCP}$ ). With this guarantee corresponds the

6 A similar solution applies to the detained person (Article $245 \$ 1 \mathrm{CCP}$ ). In literature doubts are raised as to the compliance of these provisions with the Directive: Anna Demenko, „Prawo oskarżonego do korzystania z pomocy obrońcy w świetle dyrektywy nr 2013/48/ UE - wybrane zagadnienia”, Palestra 12(2018): 18-19; Barbara Grabowska-Moroz, „Unijna dyrektywa o prawie dostępu do obrońcy - zadanie dla ustawodawcy, wyzwanie dla sądów”, Przegląd Sądowy 3(2019): 50; Tomasz Koncewicz, Anna Podolska, „Dostęp do adwokata w postępowaniu karnym. O standardach i kontekście europejskim”, Palestra 9(2017): 18-19.

7 On this aspect of the right to defence more broadly: Mar Jimeno-Bulnes, "The Right of Access to a Lawyer in the European Union: Directive 2013/48/EU”, In: ed. Tommaso Rafaraci, Rosanna Belfiore, EU Criminal Justice: Fundamental Rights, Transnational Proceedings and the European Public Prosecutor's Office, Cham: Springer Nature Switzerland, 2019, 63-64. 
content of Article $396 \$ 1 \mathrm{CCP}$, which provides the accused with the right to participate in any evidence-gathering act. There is an obligation to notify the lawyer properly about the date and place of all acts, in which the accused has the right to participate. Such obligation is crucial to guarantee the accused to exercise his/her rights of defence practically and effectively especially for acts in which the accused cannot participate. This is for example acts: 1) interrogation of a minor victim under Article 185a CCP, where, in addition, the accused must have a lawyer and if he/she does not have one, a defence counsel is appointed to him/her ex officio (Article 185a $\$ 2 \mathrm{CCP}) ; 2$ ) conducting an interrogation at the hearing without the accused because his/her presence would have an embarrassing effect on the witness (Article $390 \$ 2 \mathrm{CCP}$ ), 3) conducting some evidence-gathering act by another court (Article $396 \$ 1$ and $\$ 2 \mathrm{CCP}$ ).

The rule is that if the defence counsel fails to appear and there is no proof of delivery of the notice of the date of the action and when there is a justified supposition that the failure of appearance resulted from natural obstacles or other exceptional reasons, or finally when the defence counsel justifies his/her absence and requests for not carrying out an act in his absence - this activity is not carried out (Article $117 \$ 2 \mathrm{CCP}$ ). If the presence of a defence counsel is obligatory (and it is in "cases of obligatory defence", which will be further discussed), the actions are not carried out regardless of the reasons for not appearing, i.e. even in case of an unexcused absence (Article $117 \$ 3 \mathrm{CCP}$ ), unless the Act provides otherwise, which will be discussed later. In accordance with Article 117 $\$ 2$ a CCP, if the lawyer's failure to appear was due to an illness, in order to effectively apply for a change in the date of the procedural act, the absence must be justified by a certificate issued by a court physician (Article 117 $\$ 2$ a CCP). It should be pointed out at once that such requirement does not seem to be excessive, it was introduced in order to avoid overusing the requests for changing a date of trial with reference to health problems.

At the stage of judicial proceedings discussed in the article, there is a rule that the vast majority of evidence-gathering acts take place at the hearing, with the exception of activities the specifics of which makes it impossible (e.g. inspection of the place of the crime or questioning of a witness at the place of his/her residence when his/her appearance in court is not possible due to health reasons). Among the evidence-gathering acts 
listed in the Directive, at the stage of judicial proceedings, in practice, two of them could occur quite often: the interrogation of the accused and confrontation $^{8}$. Both of these activities will take place at the trial (during the hearing). Therefore, it is necessary to analyse how the provisions of the Polish CCP regulate the lawyer's participation at the hearing.

Already quoted rules from Article 117 CCP create an obligation to notify of any procedural acts in which the defence counsel is entitled to take part, including the date of the hearing. However, it should be noted here that a significant change of CCP has entered into force on 5 October 2019 and it may, at first glance, raise some doubts as to the compliance with the minimum standard set out in Directive 2013/48. According to Article 378a $\$ 1$ CCP, if the accused or defence counsel did not appear at the hearing, having been notified of its date, the court, in particularly justified cases, may conduct evidence-gathering acts in their absence (even if it would be justified properly in the meaning of Article $117 \$ 2$ a CCP), and in particular hear witnesses who appeared at the hearing, even if the accused has not provided any explanations yet. In a situation where the absence was justified, the defence counsel may request to repeat taking the evidence which has been taken during his/her absence. This request must be submitted at the latest at the next hearing date, of which the lawyer was duly notified, with no procedural obstacles to his/her appearance, otherwise this entitlement expires (Article $378 \mathrm{a} \$ 3$ and $\$ 4 \mathrm{CCP}$ ). It is also worth noting that for the application of the supplement of the evidentiary proceedings to be granted, the lawyer would have to show that the taking of evidence in his absence violated the procedural guarantees, including, in particular, the right to defence (which, however, does not seem difficult to prove - it would be enough to refer to being unable to ask specific questions).

This solution should be assessed in the context of Article $3 \$ 1$ of the Directive 2013/48, which requires that the Member States shall ensure that suspects and accused persons have the right of access to a lawyer in

8 The doctrine rightly emphasizes that confrontation is a type of interrogation, and therefore the rules of the Directive regarding the interrogation and the active participation of the defence counsel in the interrogation apply. - Małgorzata Wąsek-Wiaderek, "Dostęp do adwokata na wczesnym etapie postępowania karnego w prawie Unii Europejskiej”, Europejski Przegląd Sądowy 1(2019): 19. 
such time and in such a manner so as to allow the persons concerned to exercise their rights of defence practically and effectively. These two aspects should be understood that the essence of the right of access to a lawyer means to provide the accused person with competent and necessary assistance in effectively exercising his rights where the knowledge and skills of the accused person are not sufficient ${ }^{9}$.

It is worth mentioning here that from the judgment of the Court of Justice of the European Union of 5 June 2018, reference number $\mathrm{C} / 612 / 15$, arises that the particular national provisions can be examined in compliance with Article $3 \$ 1$ of the Directive $2013 / 48^{10}$. It is therefore possible to test whether a specific solution violates the obligation to provide effective and practical assistance to a lawyer.

However, it seems that Article 378a $\$ 1$ CCP can also be assessed in terms of compliance with Article $3 \$ 1$ of the Directive 2013/48. It should be noted that the Directive did not formulate a prohibition on conducting any evidence-gathering acts in the absence of a lawyer, so the court decision based on the Article 378a $\$ 1$ CCP will not automatically lead to a breach of the EU standard. Nevertheless, it should be emphasized that every polish judge has an obligation to use this provision in such a way as to ensure that the right of defence is exercised practically and effectively.

The possibility of proceeding in the justified absence of a lawyer of choice does not violate the standard of the directive. Polish CCP provisions do not prevent a defence counsel of choice from substituting for another lawyer who will appear in court on his behalf. The actual obstacles

9 Paweł Wiliński, „Zasada prawa do obrony w polskim procesie karnym”, Kraków: Kantor Wydawniczy Zakamycze, 2007, 296. See also: Lorena Bachmaier Winter, "The EU Directive on the Right to Access to a Lawyer: A Critical Assessment", In: Human Rights in European Criminal Law. New Developments in European Legislation and Case Law after the Lisbon Treaty, ed. Steffano Ruggeri, Cham: Springer International Publishing Switzerland, 2015, 121-122.

10 This judgement concerns the compliance of the Bulgarian law provisions that entitle the court to exclude the defence counsel from participation in the proceedings (against the will of the accused) due to a conflict of interest found if the lawyer defends two or more accused persons. The CJEU pointed out that such a solution is not against the Article $3 \$ 1$ of the Directive 2013/48. The judgement available on the website: curia. europe.eu and Lex/el. No. 1004947. 
on the side of the lawyer are not relevant for the assessment of EU standards. Some doubts may arise only if the proceedings in the absence of the defence counsel would concern the ex officio lawyer, where the accused has no financial means to appoint another defence counsel and the ex officio lawyer does not appoint a substitute.

However, as for the guarantee of interviewing the accused in the presence of a lawyer, it seems that in practice, at the stage of court proceedings, there will be no threat to this standard. In fact, the right to refuse to give explanations is the first instruction given to the accused by the court. This instruction precedes the hearing of the accused (Article 386 $\$ 1$ CCP). Therefore, if the accused would not want to give an explanation in the absence of his/her lawyer and the court would like to hear a case, the accused would exercise his/her right to refuse to give an explanation. What is more, the possibility of requesting the repetition of evidence-gathering acts (taken in the absence of the defence counsel, as referred to in Article $378 \mathrm{a} \$ 3 \mathrm{CCP}$ ), in the above circumstances means that it is not the end of the proceedings at the first date of the hearing. Therefore, if the court decided to exceptionally conduct evidence proceedings in the absence of the accused's defence counsel, due to the necessity of providing the right to repeat for instance the interrogation of a witness with the participation of the lawyer, the court would have to set another date for the hearing in order to enable the exercise of the right under Article $378 \mathrm{a} \$ 3 \mathrm{CCP}^{11}$.

It is worth additionally pointing out here that pursuant to Article $9 \$ 1$ and $\$ 2$ of the 2013 Directive, the accused has the right to waive "in a voluntary and unequivocal manner" the right to use the assistance of a lawyer, which should be noted in the report of the hearing. In such a case, so long as the accused agrees to carry out certain activities in

11 Contradiction of Article 378a with the EU standard is noticed by Łukasz Chojniak, „Postulat nowelizacji Kodeksu postępowania karnego - krytycznie o niektórych proponowanych zmianach”, Palestra 1-2(2019): 60-61; see also: Justyna Łacny, „Ocena rządowego projektu ustawy o zmianie ustawy - Kodeks postępowania karnego oraz niektórych innych ustaw w świetle wymogów prawa Unii Europejskiej”, Zeszyty Prawnicze Biura Analiz Sejmowych, 3(2019): 74-76. 
the absence of his/her defence counsel, the problem of compliance with the EU standard does not appear at all ${ }^{12 .}$

As a summary of this part of the article, it is worth emphasizing that at the stage of judicial proceedings, a legal problem regarding the standard of the access to a defence counsel, which the accused already has, in practice may concern only the situation referred to in Article 378a $\$ 1$ CCP in case of ex offcicio lawyer and in the context of using the assistance of a lawyer in a real and effective way.

However, as long as the regulations of Polish CCP only allow for exceptional conduct of the hearing in conditions of Article 378a $\$ 1$ CCP, not imposing such an obligation, the court will proceed in accordance with the EU standard. Therefore, since the current provisions of the Polish CCP concerning the jurisdictional stage of proceedings can be applied in accordance with the 2013 Directive, the conclusion is that the transposition of the Directive 2013/48 in relation to the mentioned stage of proceedings is fully correct. In the Polish CCP there is no provision concerning the stage of court proceedings that would prevent the defence counsel from participating in the interrogation of the accused or would prohibit taking part in evidence-gathering acts directly provided for in the Directive.

An important guarantee is also the possibility of repetition of evidence taking place in the absence of the defence counsel, although it is worth noting that in the Polish CCP there are no provisions regulating the admissibility of using evidence that was carried out in the absence of the defence counsel, e.g. incorrectly notified of the date of the hearing ${ }^{13}$. The problem of using the explanations of the accused given in the absence of the defence counsel, in practice concerns primarily the pre-trial pro-

12 It is worth mentioning the interesting issue of verifying the waiver of the right to a defence counsel. In the literature it is indicated that by referring to the interests of the judiciary, one can limit the freedom of the accused in deciding on this issue - Marek Zubik, "Konstytucyjne aspekty prawa wyboru obrony i obrońcy w sprawach karnych w perspektywie orzecznictwa Trybunału Konstytucyjnego", Europejski Przegląd Sądowy 1(2019): 15.

13 Widely on the issue of the admissibility of using suspect's explanations given in the absence of a lawyer on the basis of the Polish CCP: Andrzej Sakowicz, "Zakaz dowodowego wykorzystania wyjaśnień podejrzanego występującego bez obrońcy bądź pod nieobecność obrońcy”, Europejski Przegląd Sądowy 1(2019): 50-53. 
ceedings ${ }^{14}$. There is an extensive case law on this issue, ECHR's above all, ranging from the Salduz v. Turkey judgment or the fairly recent Beuze v. Belgium judgment ${ }^{15}$.

Despite some doubts about the proceedings in the absence of an $e x$ officio lawyer in the context of Article $3 \$ 1$ of the Directive 2013/48, it can be stated that the provisions of the Polish CCP regarding the stage of court proceedings meet the EU standard ${ }^{16}$. The abovementioned remarks concerned access to the defence lawyer that the accused has. Now the provisions of the Polish CCP regarding the accused's access to a state-paid defence counsel at the stage of court proceedings should be analysed in the context of the Directive 2016/1919.

14 Widely about this issue: Barbara Nita, „Dostęp osoby zatrzymanej do pomocy obrońcy. Uwagi w związku z wyrokiem Europejskiego Trybunału Praw Człowieka z 10 marca 2009 r. w sprawie Płonka przeciwko Polsce”, Palestra 11-12(2011): 49 and next.

15 Case of Beuze vs Belgium, Application no. 71409/10, the judgement available at: http://hudoc.echr.coe.int/eng?i=001-187802 [date of access: 20.02.2020]. The most significant judgment of the ECHR regarding this issue: the judgment of the Grand Chamber of 27 November 2008 in the case Salduz vs Turkey, Apllication no. 36391/02, available at: http://hudoc.echr.coe.int/eng?i=001-89893 [date of access: 20.02.2020]. About the Salduz doctrine see among others: Wojciech Jasiński, „Dostęp osoby oskarżonej o popełnienie czynu zagrożonego karą do adwokata na wstępnym etapie ścigania karnego - standard strasburski”, Europejski Przegląd Sądowy 1(2019), 26-28; Piotr Kardas, „Gwarancje prawa do obrony oraz dostępu do obrońcy na wstępnym etapie postępowania karnego - kilka uwag w świetle doktryny Salduz, doktryny Miranda oraz dyrektywy w sprawie dostępu do adwokata”, Europejkki Przegląd Sądowy 1(2019): 6-8.

16 The extensive report of the Helsinki Foundation for Human Rights on the implementation of the Directive 2013/48 also indicates that there are no major doubts as to the solutions of the Polish CCP regarding the stage of the court proceedings and problems with proper implementation related to the pre-trial proceedings - Adam Klepczyński, Piotr Kładoczny, Katarzyna Wiśniewska, "O (nie)dostępnym dostępie do adwokata. Raport na temat wdrożenia Dyrektywy Parlamentu Europejskiego i Rady 2013/48/UE”, Warszawa, 2017: 27-36, http://www.hfhr.pl/wp-content/uploads/2018/01/HFHR_JUSTICIA2017_ National-Report_PL.pdf, [date of access: 20.02.2020]. 


\section{ACCESS OF THE ACCUSED TO THE DEFENCE COUNSEL PAID BY THE STATE}

There are two groups of situations in the Polish criminal trial in which an ex officio lawyer is appointed for the accused. The first group is cases of "obligatory defence", where the defence counsel is appointed even without the accused's request and regardless of his/her financial status - of course, as far as the accused has no lawyer of his/her own choice. The second group is the institution of a lawyer ex officio for the accused, who proves that the difficult financial situation prevents him/her from paying the lawyer of his/her choice.

It should be recalled that the Directive of 2016 does not contain a standard which would impose an obligation on the Member States to provide each accused with the assistance of a professional lawyer paid by the state. Furthermore, it is worth pointing out that the standard of the Polish CCP relating to the appointment of an ex officio defence counsel gives more guarantees in this respect than the standard specified in the Directive of 2016.

According to Article $4 \$ 1$ of the 2016 Directive, the Member States shall ensure that suspects and accused persons who lack sufficient resources to pay for the assistance of a lawyer have the right to legal aid when the interests of justice requires so. Two criteria that can be applied to national law (as a condition for determining whether the legal aid paid by the state should be granted) are provided for in Article $4 \$ 2$ of the 2016 Directive. Therefore, it is possible to examine the financial situation of the accused ("a means test"), but also the necessity of granting ex officio the legal aid in a specific case ("a merits test") or both.

It is worth noting that the Polish legislator has not decided to introduce a criterion of necessity - "a merits test" that should be related to seriousness of the criminal offence, the complexity of the case and the severity of the sanction (these auxiliary criteria are listed in Article $4 \$ 1$ of the 2016 Directive), or possibly also in connection with the assessment of the resourcefulness of the accused. The abovementioned factors are not relevant in the Polish CCP. Therefore, the only criterion for assessing whether the accused should be granted an ex officio defence counsel is that the accused has duly proved that he/she is not able to bear the costs of defence 
without prejudice to the necessary maintenance of himself and the family (Article $78 \$ 1 \mathrm{CCP}$ ), i.e. the criterion of financial standing ("means test").

Moreover, as indicated above, there are also cases in which the Polish legislator decided to guarantee the assistance of a lawyer paid by the state regardless of the financial status of the accused. These are the cases of "obligatory defence". It is not the purpose of this article to discuss this issue in detail, so it is sufficient to point out, for example, that obligatory defence applies to the accused in a particularly difficult situation related to their mental health (doubts regarding sanity), physical disabilities (deaf, dumb or blind accused), or age (accused under 18 years old) - Article 79 $\$ 1$ CCP. The accused must also have a defence counsel in cases of felonies (Article 80 of the CCP - in this case the Polish legislator applied the criterion of the importance of the case), and whenever the court decides so or when it deems it necessary due to other circumstances impeding the defence (Article $79 \$ 2 \mathrm{CCP}$ ). In accordance with Article $79 \$ 3 \mathrm{CCP}$ the defence counsel's participation is obligatory in the hearings and the sittings, in which the participation of the accused is obligatory.

It is important to pay attention to the issue of deprivation of liberty as a circumstance justifying the granting of an ex officio lawyer. The Directive 2016/1919 contains an important requirement for such a case. In Article $4 \$ 4$, it was therefore indicated that the criteria of necessity ("merits test"), if they are used by the Member States to assess the necessity of appointing an ex officio lawyer, will be met whenever the accused is brought before a competent court or judge to make a decision on imprisonment or when he/she is already deprived of liberty. It should be pointed out that the above criterion for the assessment of the Polish solutions is in fact irrelevant because the Polish legislator has not decided to introduce the "merits test".

If the accused is deprived of liberty and his/her financial situation does not allow him/her to pay the lawyer of his/her own choice (and therefore he/she has no savings or close family that could help the accused), then the court will appoint a defence counsel ex officio to such an accused - even in the simplest case. The aforementioned content of Article $4 \$ 4$ of the Directive 2016/2019 should, however, provide the courts with a kind of "hint" when examining applications for the appointment of an ex officio lawyer for an accused deprived of liberty, while refusal decisions should 
always be well-thought-out and motivated. The court may always withdraw the appointment of a defence counsel if it turns out that there are no circumstances on the basis of which he/she was appointed (Article 78 $\$ 2 \mathrm{CCP}$ ), and the costs of the appointment may finally be charged to the accused, if a conviction was made (Article 627 CCP and Article 618 $\$ 1$ point $11 \mathrm{CCP})$.

The abovementioned solution adopted in the Polish CCP regarding the juridical stage meets the standard of the Directive of $2016^{17}$. Proper execution of the guarantees provided for by the law depends on the specific court decision, which, moreover, if negative (refusal to appoint a lawyer $e x$ officio), is subject to interlocutory appeal (Article $81 \$ 1$ a CCP).

Another issue worth mentioning here is the time in which the Member States should ensure ex officio legal aid. In accordance with Article $4 \$ 5$ of the Directive 2016/1919, the Member States shall ensure that legal aid is granted without undue delay, and at the latest before questioning by the police, by another law enforcement authority or by a judicial authority, or before the investigative or specific evidence-gathering acts. In the Polish CCP there is no regulation which sets a deadline for granting an ex officio lawyer, what is more, there is no requirement that it should be done immediately. So, it all depends on the court's practice, although it seems that it would be worth regulating this issue at least as modelled on the solution of Article $254 \$ 1$ CCP, in which the legislator has provided for a 3-day period for examining the application for repealing or changing the preventive measure. Such period could be provided for examining the request for appointment of defence counsel ${ }^{18}$.

17 Doubts regarding the defence ex officio in the doctrine relate to the pre-trial stage only: Barbara Grabowska-Moroz, "Prawo dostępu do obrońcy w świetle prawa europejskiego", Warszawa: HFHR, 2018, 40-42, DOI: https://www.hfhr.pl/wp-content/uploads/2018/05/Prawo-dost\%C4\%99pu-do-obroncy-w-swietle-prawa-UE-FIN.pdf

18 The doctrine postulates that the decision on the appointment of an ex officio lawyer upon a request should be made on the basis of the statement of the accused that there are grounds for this, regarding his/her financial situation, and that the examination of this financial situation would take place after the appointment of a defence counsel - Sławomir Steinborn, "Dostęp do obrońcy na wczesnym etapie postępowania karnego. Uwagi de lege lata i de lege ferenda", Europejski Przegląd Sądowy 1(2019): 40-41. 
At the stage of judicial proceedings, in practice, the problem of the time of examining such an application is revealed in a situation, in which the accused's application for the appointment of a defence counsel ex officio arrives before the designated date of the hearing. It is worth noting that in the Act that entered into force on 5 October 2019, the legislator explicitly indicated that it implements Directive 2013/48 and the Directive of the European Parliament and of the Council (EU) 2016/343 of 9 March 2016 on strengthening certain aspects of the presumption of innocence and law to attend the trial in criminal proceedings ${ }^{19}$. It could be argued that this Act introduces some strengthening of the EU standard in the field of access to a lawyer at the stage of court proceedings. The Polish legislator has removed from Article $353 \$ 5$ CCP some uncertainty about the effect of submitting an application for appointment of a lawyer after the deadline. Before changing this provision, an application for the appointment of an ex officio defence counsel should be submitted within 7 days from the date of the delivery of the summons on the hearing or the notice of its date. The application submitted after the deadline would be examined, only if it did not necessitate a change in the date of the hearing. Therefore, if the 7-days term was exceeded, even if the court set further dates for the hearing, the application to appoint a defence counsel was left without consideration ${ }^{20}$.

Currently, this issue is regulated by a new provision - Article 338b CCP. Pursuant to this rule, the deadline for submitting an application for the appointment of a defence counsel is 7 days from the date of delivery of a copy of the indictment, and if submitting a request after the deadline would necessitate a change in the date of the hearing, the request shall be examined immediately after the date of the hearing. Therefore, the legislator resolved the doubt as to whether the application should be considered after the hearing - in favour of the accused.

It should be considered whether, despite the changes, such a restriction still contradicts the EU standard. It should be borne in mind that in the analysed situation, the premises for appointing an ex officio lawyer may be fully valid, but only the accused has failed to meet the prescribed term.

19 Official Journal EU L 65 of 11/03/2016.

20 Krzysztof Eichstaedt, "Commentary on the Article 353 CCP”, In: Code of Criminal Procedure. Comment, ed. Dariusz Świecki, Warszawa: Wolters Kluwer, 2018, 1314. 
And if the court heard the accused who could not afford to pay the lawyer by choice and who submitted a too-late application for the appointment of an ex officio defence counsel, then the standard of the Directive 2016/1919 would not be met. It is worth noting that the Directive 2016/1919 also directly (in Article $2 \$ 1$ ) and exactly as the Directive 2013/48 indicates the activities in which the accused should have an opportunity to have a lawyer paid by the state. There is the interrogation of the accused among them. It seems, therefore, that if the court would like to conduct a hearing, without examining the too-late application of the accused for appointing a lawyer, it should be eventually limited to the interrogation of witnesses but not as part of the confrontation with the accused. It should be borne in mind, however, that without hearing the accused (except the situation where the court decides to hold a hearing in his/her absence), the judicial process cannot be opened at all.

It seems that in such a case, to meet the EU standard and to act in accordance with the provisions of the CCP as well, the court should act as follows. If the accused does not agree to be interviewed without a defence counsel (waiving the right of access to a lawyer within the meaning of Article 9 of the 2013 Directive in from $\$ 9$ of preamble to the Directive 2016/1919), the court should instruct the accused explicitly that he/she may declare the wish to refuse to give explanation. Moreover, the accused could even refuse to respond to the content of the complaint, which should be registered. In such a case, the court would limit the proceedings against him/her to those reading the explanations from the pre-trial proceedings (Article $389 \$ 1 \mathrm{CCP}$ ) and could carry out other planned evidence-gathering acts, not explicitly mentioned in the Directives.

However, in order to allow the substantive consideration of the application for the appointment of an ex officio lawyer, the court should not, in this case, end the proceedings, and should set a further date for the hearing. If the late motion was accepted despite the lack of an explicit provision for it, the court should consider the possibility of repeating the evidence taken, especially if the appointed defence counsel would request it, indicating e.g. the need to ask additional questions. In any case, however, the court should allow the hearing of the accused in the presence of an appointed lawyer, or carry out a confrontation again, since these activities were explicitly mentioned in the Directive - indicating the scope of its 
validity. It is also worth mentioning that when it comes to the deadline for submitting an application for the appointment of an ex officio lawyer and the possible consequences of his/her failure to comply with it, the accused is instructed in providing him/her with a copy of the indictment (Article $338 \$ 1$ a CCP). So, if, despite a clear instruction, the accused does not meet the deadline, in fact he/she deprives himself/herself of the rights provided in the Polish CCP.

\section{ACCESS TO A LAWYER IN APPEAL PROCEEDINGS}

In accordance with Article $458 \mathrm{CCP}$ the provisions on proceedings before the court of first instance shall apply mutatis mutandis to appeal proceedings, unless certain matters are clearly regulated differently. Focusing here only on differences from the proceedings at first instance, it is worth pointing out that the provisions on appeal proceedings may be considered as ensuring less guarantee as regards the access to a lawyer in the scope of the Directive 2013/48. Of course, it should be borne in mind that the nature of the appeal proceedings is different from that of proceedings before a court of the first instance, although it is worth noting that the model of the Polish proceedings at the second instance is a reformatory model. This means that before the court of the second instance it is possible to take evidence that was not carried out at the first instance.

Moving straight to the merits, it should be noted that defence counsel of the accused will be notified of the date of the appeal hearing on general principles. It is worth pointing out, however, that according to Article 450 $\$ 3 \mathrm{CCP}$ a failure to appear of parties or lawyers duly notified of the date of the hearing does not stop the examination of the case, unless their presence is obligatory. In principle, the presence is obligatory in cases of "obligatory defence" or always when the court decides so (Article $450 \$ 2$ CCP). Reflecting on the relation of this provision to the norm discussed above, regarding the conduct of the trial at the first instance in the absence of a lawyer, it should be noted that Article $450 \$ 3 \mathrm{CCP}$ is here a lex specialis. Firstly, this results in the principle that regardless of the reasons for the lawyer's failure to appear, the appeal hearing may take place (unless there is a case of obligatory defence). Secondly, it would probably have to be considered that the appeal 
procedure does not apply to the provision enabling repetition of the action at the request of a lawyer who could not participate in the hearing.

If, despite the excused absence of the lawyer, the court of the second instance decides to interrogate the accused (or - which in practice is unusual, but is not excluded - will conduct a confrontation, presentation, or trial experiment) and does not take into account the request to postpone the hearing in order to enable the appearance of the defence counsel, this standard of the Directive 2013/48 will not be met. It therefore needs to be emphasized that the provision of Article $450 \$ 3 \mathrm{CCP}$ only gives the opportunity to conduct a hearing, under no circumstances it obliges the appeal court to do so. Also, in the discussed situation, it depends on the decision of the court whether the standard of Directive 2013/48 in a specific case will be guaranteed, but it is possible to achieve without the interference of the legislator. The appeal court, wanting to additionally hear the accused (bearing in mind that there is no appeal against his decision), should not use the option of Article $450 \$ 3 \mathrm{CCP}$, and simply postpone the hearing. This would enable the interrogation of the accused in the presence of his/her lawyer.

Attention should also be paid to the specific solution functioning in the appeal proceedings regarding the presence of the accused himself/ herself at the hearing. According to Article 451 CCP the appeal court has the option of refraining from bringing the accused person deprived of liberty to the hearing, if it is considered that the presence of a lawyer is sufficient. If there is no defence counsel appointed, the court appoints a lawyer ex officio. It is worth adding that in the first instance proceedings it is not possible to disregard the request to bring the accused to the hearing just because he/she has a defence counsel. When assessing this provision from the perspective of the European standard, it should be noted that the Directives of 2013 and of 2016 generally do not prevent such a solution. The only doubt concerns the right to direct contact with a lawyer, the necessity of which may, after all, be revealed depending on the course of the appeal hearing. In such a case, the appeal court should bear in mind that Article $451 \mathrm{CCP}$ also gives only the option of refraining from bringing the accused to the hearing ${ }^{21}$. If the court considers that the right of the accused

21 The doctrine indicates that if the accused submits a motion for bringing to court, it generally should be granted and the presence of a defence counsel can be considered 
to have direct contact with the lawyer may be not guaranteed, the hearing should be postponed.

\section{FINAL REMARKS}

To sum it up, it should be pointed out that despite the controversial solutions regarding the possibility of proceeding in the absence of the accused's defence counsel, even justified by a court physician, the provisions of the Polish CCP give the opportunity to maintain the standard of Directive 2013/48. However, it will depend on the court's decisions in a particular case. As long as the provisions relating to the stage of proceedings before the court give only the opportunity to proceed in the absence of a lawyer, and do not oblige to it, it can be said that the Polish provisions meet the EU standard resulting from the Directive of 2013.

As for the standard arising from Directive 2016/1919, Polish provisions regarding the stage of judicial proceedings meet the European standard to a level even higher than the minimum. The only significant problem may arise from the obligation to submit an application for the appointment of an ex officio defence counsel within a specified period of time. However, since the accused is informed of this obligation, and the court must still consider the application brought after the deadline, the author does not see any breach of the standard resulting from the Directive. Although, it needs to be emphasized that courts should always use the above-mentioned provision of the CCP, which to some extent limits the accused's right of access to a lawyer, with particular attention and prudence. The provisions enabling the repetition of certain evidence-gathering acts should be applied in such a way that there are no grounds for challenging decisions taken due to violations of the rights of the defence, also to a certain extent arising from the EU Directives.

sufficient only exceptionally - Dariusz Świecki, "Commentary on the Article 451 CCP", In: Code of Criminal Procedure. Comment, ed. Jerzy Skorupka, Warszawa: C. H. Beck, 2018, 1142-1143. 


\section{REFERENCES}

Bachmaier Winter, Lorena. "The EU Directive on the Right to Access to a Lawyer: A Critical Assessment", In: Human Rights in European Criminal Law. New Developments in European Legislation and Case Law after the Lisbon Treaty, ed. Steffano Ruggeri, Switzerland: Springer International Publishing, 2015, 121-122.

Chojniak, Łukasz. 2019. „Postulat nowelizacji Kodeksu postępowania karnego krytycznie o niektórych proponowanych zmianach”, Palestra 1-2: 56-68.

Demenko, Anna. 2018. „Prawo oskarżonego do korzystania z pomocy obrońcy w świetle dyrektywy nr 2013/48/UE - wybrane zagadnienia", Palestra 12: 13-20. Eichstaedt, Krzysztof. "Commentary on the Art. 353 CCP”, In: Code of Criminal Procedure. Comment, ed. Dariusz Świecki. 2018. Warszawa: Wolters Kluwer. Grabowska-Moroz, Barbara. 2018. „Prawo dostępu do obrońcy w świetle prawa europejskiego", Warszawa: HFHR, https://www.hfhr.pl/wp-content/uploads/2018/05/Prawo-dost\%C4\%99pu-do-obroncy-w-swietle-prawa-UEFIN.pdf, February 20, 2020.

Grabowska-Moroz, Barbara. 2019. „Unijna dyrektywa o prawie dostępu do obrońcy - zadanie dla ustawodawcy, wyzwanie dla sądów”, Przegląd Sądowy 3: 45-59.

Jasiński, Wojciech. 2019. „Dostęp osoby oskarżonej o popełnienie czynu zagrożonego karą do adwokata na wstępnym etapie ścigania karnego - standard strasburski”, Europejski Przegląd Sądowy 1, 24-30.

Jimeno-Bulnes, Mar. "The Right of Access to a Lawyer in the European Union: Directive 2013/48/EU”, In: ed. Tommaso Rafaraci, Rosanna Belfiore, EU Criminal Justice: Fundamental Rights, Transnational Proceedings and the European Public Prosecutor's Office, Cham: Springer Nature Switzerland, 2019, 63-64.

Judgment of the Court of Justice of the European Union of 5 June 2018, reference number C/612/15, curia.europe.eu, February 15, 2020 and Lex/el. No. 1004947.

Judgment of the European Court of Human Rights of 27 November 2008 in the case Salduz vs Turkey, Apllication no. 36391/02, http://hudoc.echr.coe.int/ eng?i=001-89893, February 20, 2020.

Judgment of the European Court of Human Rights of 9 November 2018 in the case of Beuze vs Belgium, Application no. 71409/10, http://hudoc.echr.coe. int/eng?i=001-187802, February 20, 2020.

Kardas, Piotr. 2019. „Gwarancje prawa do obrony oraz dostępu do obrońcy na wstępnym etapie postępowania karnego - kilka uwag w świetle doktryny Sal- 
duz, doktryny Miranda oraz dyrektywy w sprawie dostępu do adwokata”, Europejski Przegląd Sądowy 1: 4-10.

Klepczyński, Adam. Kładoczny, Piotr. Wiśniewska, Katarzyna. 2017. „O (nie) dostępnym dostępie do adwokata. Raport na temat wdrożenia Dyrektywy Parlamentu Europejskiego i Rady 2013/48/UE", Warszawa: HFHR: http:// www.hfhr.pl/wp-content/uploads/2018/01/HFHR_JUSTICIA2017_National-Report_PL.pdf, February 20, 2020.

Koncewicz, Tomasz. Podolska, Anna. 2017. „Dostęp do adwokata w postępowaniu karnym. O standardach i kontekście europejskim”, Palestra 9: 9-23.

Łacny, Justyna. 2019. „Ocena rządowego projektu ustawy o zmianie ustawy - Kodeks postępowania karnego oraz niektórych innych ustaw w świetle wymogów prawa Unii Europejskiej”, Zeszyty Prawnicze Biura Analiz Sejmowych, 3: 70-78.

Ponikowski, Ryszard. Zagrodnik, Jarosław. 2018. „Commentary on the Art. 401 CCP”. In: Code of Criminal Procedure. Comment, ed. Jerzy Skorupka, Warszawa: C. H. Beck. Pronouncement of Ombudsman of 4 July 2018 to the Minister of Justice: https://www.rpo.gov.pl/sites/default/files/Wyst $\%$ C $4 \% 85$ pienie $\% 20$ do\%20Ministra\%20Sprawiedliwo \% C5\%9Bci\%20w\%20sprawie $\% 20$ prawa $\% 20$ osoby\%20zatrzymanej\%20do\%20 pomocy\%20prawnej.pdf February 15, 2020.

Reply of the Minister of Justice to the Ombudsman's request of 18 October 2018: https://www.rpo.gov.pl/sites/default/files/Odpowied\%C5\%BA\%20MS\%20 18.10.2018_0.pdf February 15, 2020.

Sakowicz, Andrzej. 2019, „Zakaz dowodowego wykorzystania wyjaśnień podejrzanego występującego bez obrońcy bądź pod nieobecność obrońcy”, Europejski Przegląd Sądowy 1: 47-54.

Steinborn, Sławomir. 2019. „Dostęp do obrońcy na wczesnym etapie postępowania karnego. Uwagi de lege lata i de lege ferenda”, Europejski Przegląd Sądowy 1: 38-46.

Świecki, Dariusz. 2018. "Commentary on the Art. 451 CCP”, In: Code of Criminal Procedure. Comment, ed. Jerzy Skorupka, Warszawa: C. H. Beck.

Wąsek-Wiaderek, Małgorzata. 2019. „Dostęp do adwokata na wczesnym etapie postępowania karnego w prawie Unii Europejskiej”, Europejski Przegląd Sądowy 1: 17-23.

Wiliński, Paweł. „Zasada prawa do obrony w polskim procesie karnym”, Kraków: Kantor Wydawniczy Zakamycze, 2007, 296.

Zubik, Marek. 2019. „Konstytucyjne aspekty prawa wyboru obrony i obrońcy w sprawach karnych w perspektywie orzecznictwa Trybunału Konstytucyjnego", Europejski Przegląd Sądowy 1: 11-16. 